\title{
Erratum zu: Distributionssysteme
}

\section{Erratum zu:}

Kapitel 3 in: C. Tripp, Distributions- und Handelslogistik, https://doi.org/10.1007/978-3-658-34532-7_3

Wir möchten auf Folgendes hinweisen:

Kapitel 3.1.2, S. 176: Aufgrund eines technischen Fehlers während der Buchherstellung wurde Abbildung 3.4 nicht korrekt dargestellt. Die Abbildung wurde durch das Erratum korrigiert und ist auch in diesem Erratum-Kapitel zu finden. 

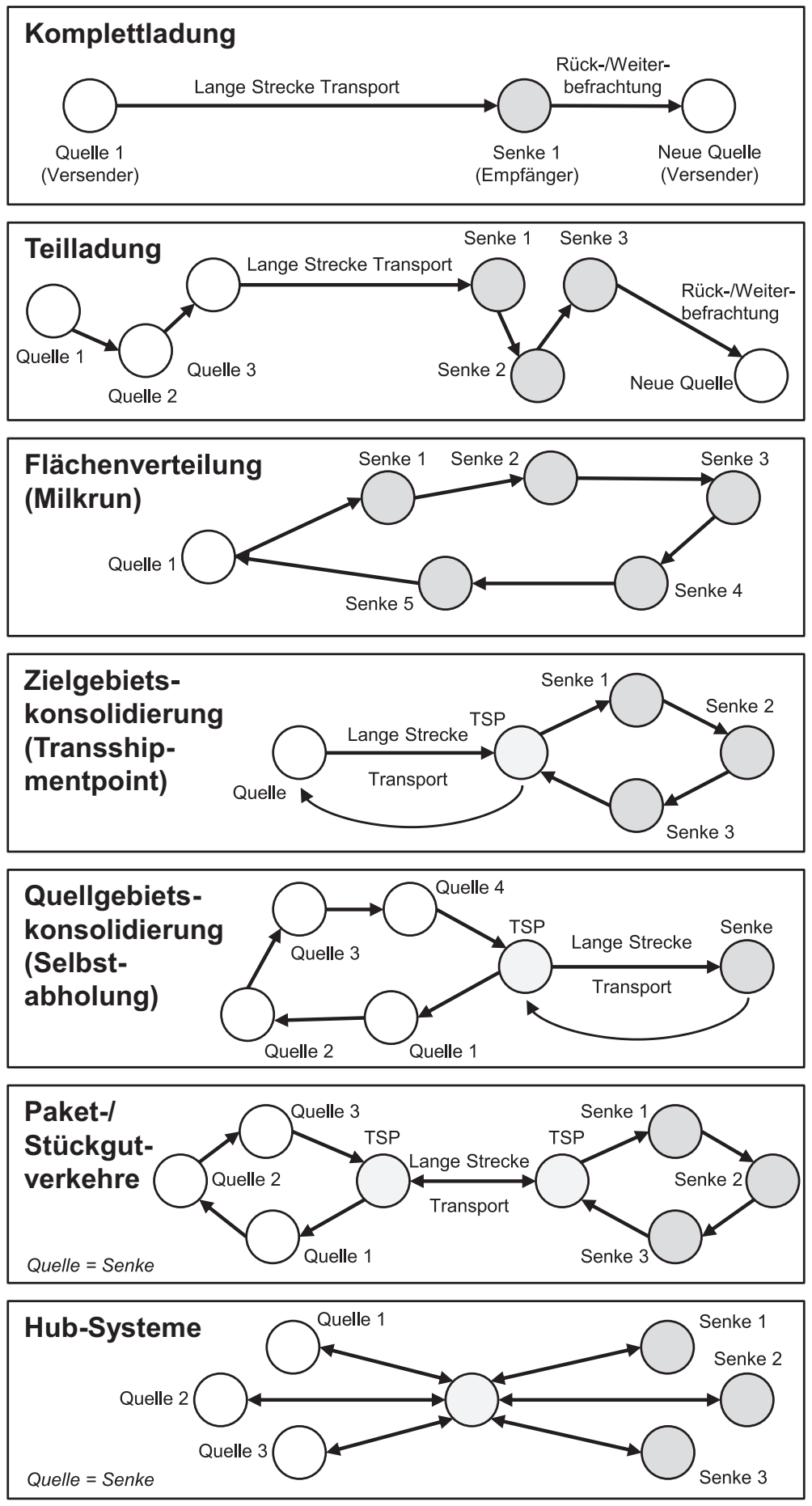

Abb. 3.4 Grundlegende Transportmuster in der Distribution. (Quelle: Eigene Erstellung) 